\title{
Enterprise Risk Management In The Oil And Gas Industry: An Analysis Of Selected Fortune 500 Oil And Gas Companies' Reaction In 2009 And 2010
}

Violet C. Rogers, Stephen F. Austin State University, USA Jack R. Ethridge, Stephen F. Austin State University, USA

\begin{abstract}
In 2009, four of the top ten Fortune 500 companies were classified within the oil and gas industry. Organizations of this size typically have an advanced Enterprise Risk Management system in place to mitigate risk and to achieve their corporations' objectives. The companies and the article utilize the Enterprise Risk Management Integrated Framework developed by the Committee of Sponsoring Organizations (COSO) as a guide to organize their risk management and reporting. The authors used the framework to analyze reporting years 2009 and 2010 for Fortune 500 oil and gas companies. After gathering and examining information from 2009 and 2010 annual reports, 10-K filings, and proxy statements, the article examines how the selected companies are implementing requirements identified in the previously mentioned publications.
\end{abstract}

Each section examines the companies' Enterprise Risk Management system, risk appetite, and any other notable information regarding risk management. One observation was the existence or nonexistence of a Chief Risk Officer or other Senior Level Manager in charge of risk management. Other observations included identified risks, such as changes in economic, regulatory, and political environments in the different countries where the corporations do business. Still others identify risks, such as increases in certain costs that exceed natural inflation, volatility and instability of market conditions. Fortune 500 oil and gas companies included in this analysis are ExxonMobil, Chevron, ConocoPhillips, Baker Hughes, Valero Energy, and Frontier Oil Corporation.

An analysis revealed a sophisticated understanding and reporting of many types of risks, including those associated with increasing production capacity. Specific risks identified by companies included start-up timing, operational outages, weather events, regulatory changes, geo-political and cyber security risks, among others. Mitigation efforts included portfolio management and financial strength. There is evidence that companies in later reports (2013) are more comprehensive in their risk management and reports as evidenced by their 10-K and Proxy Statements (Marathon Oil Corporation, 2013).

Keywords: Accounting; Risk; Oil and Gas Accounting; Chief Risk Officer; Enterprise Risk Management

\section{INTRODUCTION}

\section{Enterprise Risk Management}

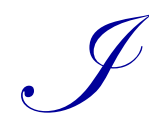
mplementing and using Enterprise Risk Management is a necessary and growing activity in today's unstable economy. The Committee of Sponsoring Organizations defines Enterprise Risk Management as a process affected by an entity's board of directors, management and other personnel; this process is applied within a corporation, designed to identify potential events which may affect the entity, and manage risks to 
be within its risk appetite. In addition, Enterprise Risk Management is a process that provides reasonable assurance regarding the achievement of the entity's objectives. Companies can identify, assess, respond, and monitor the outcomes of the corporation's leading risk factors with an Enterprise Risk Management system in place.

This article uses the framework from the "Report on the Current State of Enterprise Risk Oversight" published by the AICPA Business, Industry, \& Government Team and the "Enterprise Risk Management Initiative" at North Carolina State University to analyze reporting years 2009 and 2010 for selected Fortune 500 oil and gas companies. After gathering and examining information from 2009 and 2010 annual reports, 10-K filings, and proxy statements, the article examines how the selected companies are implementing requirements identified in the previously mentioned publications. Fortune 500 oil and gas companies included in this analysis are ExxonMobil, Chevron, ConocoPhillips, Baker Hughes, Valero Energy, and Frontier Oil Corporation.

\section{The Companies}

\section{ExxonMobil}

In 2009, ExxonMobil dominated the Fortune 500 list as the largest company in America with their sales reaching as high as $\$ 275.56$ billion and gross income of $\$ 75.79$ billion. In 2010 , sales soared to a remarkable $\$ 341.58$ billion and gross income rose to $\$ 90.92$ billion. Moreover, ExxonMobil is a well-established corporation within the oil and gas industry. ExxonMobil's executives expanded on the corporation's long-standing risk management system. ExxonMobil's risk management system encourages a risk-averse philosophy to govern the corporation's business decisions; additionally, this risk/reward ideology discourages executives from taking inappropriate risks. The risk management section of ExxonMobil's annual statement identities the leading areas of risk and the actions taken by the corporation to mitigate these risks.

ExxonMobil utilizes the risk management section of the 2010 annual statement to itemize a few of the major risks associated with increasing the corporation's production capacity. For instance, these production quantity increases are subject to an assortment of risks, including project start-up timing, operational outages, reservoir performance, crude oil and natural gas prices, weather events, and regulatory changes. In addition, ExxonMobil's volume of cash flow depends greatly on crude oil and natural gas prices. To maintain the trust and support of investors, ExxonMobil details the manner in which they mitigate the risks listed above. As addressed in ExxonMobil's 2009 Annual Statement (report), "The Corporation has a large and diverse portfolio of development projects and exploration opportunities, which helps mitigate the overall political and technical risks of the Corporation's upstream segment and associated cash flow." Furthermore, the risk due to failure or delay of an individual project is mitigated by the corporation's financial strength, debt capacity, and well diversified portfolio. As the corporation continues to mitigate political and technical risks, ExxonMobil focuses on maximizing shareholder value. After evaluating the factors associated with ExxonMobil's risk management system, it is appropriate to conclude the corporation has constructed a well-developed system of mitigating risk; moreover, this system is based on a risk-averse philosophy. Despite the well thought-out risk management system, ExxonMobil's 2009 Annual Report fails to mention the position of a Chief Risk Officer. The assessment of ExxonMobil's Enterprise Risk Management system leads to the conclusion that the risk-adverse approach has been quite successful; however, developing the position of Chief Risk Officer would improve the management of the overall system. It is probable that duties of a Chief Risk Officer are handled by someone and their team housed within the upper echelon of management. Albeit, appropriate reference to such person and team, should be reported.

Other publications that discuss risks include The Lamp and ExxonMobil 2011 Corporate Citizenship Report, which is published bi-annually and includes climate changes, environmental challenges, math and science projects, etc. The Lamp is published for ExxonMobil's shareholders. The latest issue of The Lamp included partnerships with the National Oil Company of Columbia, an article on Canadian shale and an article on Angola Block 15. The Angola site employs 78\% Angolans. A chart of risks, mitigation methods, and mitigation method/control effectiveness is presented at the end of this article for all companies. 
Chevron

In 2009, Chevron ranked third among the Fortune 500 corporations, with revenue soaring as high as $\$ 263$ billion, leaving many of their competitors in their wake. Chevron has proven to be a successful corporation within the oil and gas industry. While dominating the market, Chevron has implemented one of the most impressive and comprehensive Enterprise Risk Management (ERM) systems as evidenced by their continuing identification, assessment, and response to risks. Chevron utilizes the annual statements to inform current and potential shareholders of the possible risks involved in the oil and gas industry. In particular, Chevron identified potential risks surrounding the volatility of crude oil prices, infrequent events or transactions, changing economic conditions, varying regulation and political risk within affiliated countries, and some increases in certain costs which exceed the natural inflation rate. To reassure investors on Chevron's ability to provide adequate responses to these risks, Chevron continually evaluates its' risk, opportunities, and closely monitors developments. After reviewing Chevron's risk factors, it is reasonable to conclude that Chevron's Enterprise Risk Management system is among the most developed and complex systems out of the six oil and gas companies reviewed.

Although Chevron has an advanced risk management system, they did not mention the position of Chief Risk Officer. The extensive list of risk factors led the authors to conclude that Chevron is strongly risk-averse. Additionally, the company's investment endeavors are influenced by Chevron's risk tolerance level. After reviewing Chevron's 2010 Proxy Statement, the section regarding the oversight of risk addresses who is responsible for risk assessment and management. Specifically, the 2010 Proxy Statement specifies that oversight responsibility falls upon the Audit Committee to assist the Board in monitoring Chevron's risk exposure while also developing guidelines and policies to govern processes for managing risks. The Committee discusses Chevron's policies with respect to risk assessment and risk management. As such, Chevron has a well-developed and documented Enterprise Risk Management system.

\section{ConocoPhillips}

In 2009, ConocoPhillips moved ahead of General Motors to claim fourth spot among the Fortune 500 companies. At this time, the corporation earned $\$ 149.34$ billion in gross sales and $\$ 8.91$ billion in net income. In 2010 , these figures increased to $\$ 189.44$ billion and $\$ 11.36$ billion, respectively. ConocoPhillips' success is not limited to the oil and gas industry. Their 2009 Annual Report mentions the company's claims to possess a high expertise in risk assessment; this is demonstrated in their exploration strategy into the frontier basins. ConocoPhillips seeks to engage the use of frontier basins by securing attractive positions that balance risk and cost. This leads to the consideration that ConocoPhillips has a risk-neutral appetite within their day-to-day procedures and risk management process.

Throughout the annual report, ConocoPhillips uses the key words safe and reliable; moreover, the report mentions that ConocoPhillips always uses a disciplined approach when conducting business. The following statement from the 2009 Annual Report was taken into consideration when considering the company's risk appetite: "With robust captured opportunities on hand, we are not pursuing new areas that cannot be competed favorably." In capturing such robust opportunities, ConocoPhillips is portrayed to be risk-neutral.

The 2009 and 2010 Annual Reports do not mention the position of a Chief Risk Officer or other Senior Level Manager. However, in the reading, it is obvious that ConocoPhillips has a respectable and thorough process for managing risks. After reviewing ConocoPhillips' 2010 Proxy Statement regarding risk oversight, responsibility is assigned to ConocoPhillips' Management. In addition, the Board of Directors has oversight responsibility for Risk Management programs. In this role, the Board of Directors' reviews and designs implementation of the risk management processes, assuring they are functioning as intended. Delegation occurs to individual Board committees, such as the Audit and Finance Committee. Additionally, the Audit and Finance Committee routinely discusses the corporation's risk assessment and risk management policies to verify that the programs are operating as they were designed. Furthermore, the Chairman of the Audit and Finance Committee conducts an annual meeting where the Chairs of each Board committee gather to discuss the functionality of the current risk management programs. Moreover, within the course of the year, the Board of Directors receives regular updates from the respective Board committees identifying individual areas of concern. All said, the systems appear comprehensive. 
Valero Energy

In 2009, Valero Energy ranked tenth on the Fortune 500 list, following Hewlett-Packard, with $\$ 64.60$ billion in revenue and a negative $\$ 273.00$ million in net income. In 2010, Valero's financial position changed drastically, producing revenue of $\$ 82.23$ billion and increasing the company's net income to a positive $\$ 923.00$ million. Valero is a highly competitive oil and gas company within the industry. Surprisingly, Valero's 2009 Annual Report contains no reference to the implementation of a risk management process. Throughout the 2009 Annual Report, Valero stressed the importance of taking aggressive steps to combat future challenges, while growing more competitive among the oil and gas industry.

During 2009, Valero took advantage of the opportunity to invest in alternative energy. Specifically, Valero entered the ethanol business in 2009 by acquiring seven ethanol plants in the Midwest. This acquisition, along with the purchase of three additional ethanol plants during 2009, proved to be quite beneficial to the corporation, increasing the capacity by 1.1 billion gallons per year. This causes Valero to be one of the largest producers of ethanol in the country. Valero's ability to recognize the opportunity to invest in alternative energy was promising to the corporation's future success; this is also a statement on the company's level of tolerable risk. In the 2009 Annual Report, Valero released a statement mentioning every investment, every action, must be directly and efficiently tied to the achievement of the company's vision. This serves as evidence of the use of a risk management process to base the corporation's decisions. However, even though Valero had a seemingly advanced process to manage risk, evidence of a Chief Risk Officer was non-existent.

Valero dropped from the tenth to the twenty-sixth spot in the 2010 Fortune 500 list. The 2010 Proxy Statement contains a section regarding risk management and the Board's responsibility toward risk management. These responsibilities include receiving reports from members of senior management on areas of material risk. These reports are used to enable the Board to understand and manage Valero's risk identification, management, and mitigation strategies. Afterward, the chairperson of each Committee reports on the matters to the Board. The Board also believes risk management is an integral part of Valero's annual strategic planning process. Valero's Chief Audit Officer annually prepares a comprehensive risk assessment report, which is reviewed by the Audit committee. Furthermore, this report identifies Valero's material business risks and internal controls that respond to and mitigate those risks.

Baker Hughes, Inc.

In 2009, Baker Hughes Inc. was number 227 on the Fortune 500 list, with revenue of $\$ 9.66$ billion and net income of $\$ 0.42$ billion. In 2010, Baker Hughes moved to number 243 on the Fortune 500 list, sales rose to $\$ 14.41$ billion and net income increased to $\$ 0.81$ billion. In contrast to the aforementioned companies, Baker Hughes resides within the oil well services and equipment industry. The 2009 Annual Report includes a lengthy section devoted entirely to identifying the corporation's material risks. This section also details the effect of the risk on Baker Hughes and specifies what steps are being taken to combat these risks. Baker Hughes material risks include volatility of oil and natural gas prices, factors affecting demand for oil and natural gas, seasonal and adverse weather conditions, a highly competitive market, geopolitical risks, and terrorism risks. However, Baker Hughes' impressive risk management process failed to identify a Senior Level Manager devoted to leading this process. Furthermore, Baker Hughes did not mention what part of the company was responsible for managing risk.

Baker Hughes' risk appetite is supported by the company's competitive decision-making process within the market. The Corporation retains their position in the highly competitive market by creating value for their customers through developing new and reliable products and services. Baker Hughes decided to take on a greater level of risk when searching for potential growth areas within the operating segment; this plan was implemented to assist the corporation in excelling in an active and competitive market. The company's philosophy is that with big risk comes big reward; in this case, reward references the company's ability to remain competitive in a highly aggressive market. Baker Hughes' risk management system can affect the company's financial position. However, with such a mature Enterprise Risk Management system in place, Baker Hughes is able to undertake a greater level of risk compared to other companies who may have poorly assessed their risks. In conclusion, it appears that Baker Hughes' decisions are based on a risk-seeking appetite. The 2010 Proxy Statement does not explore the risk 
management system; however, 2010 Annual Report details oversight risk analysis and risk management procedures. The responsibility of reviewing the guidelines and policies on Enterprise Risk Management falls upon the Audit and Ethics Committee, including risk assessment and risk management related to the company's major financial risk exposures and the steps management has taken to monitor and mitigate such exposures. The Chief Compliance Officer provides a report to the committee, including updates pertaining to the status of the company's compliance with its standards, policies, procedures, and processes. Baker Hughes maintains an Enterprise Risk Management process which reviews the business's risk framework, including an assessment of external risk, internal risks, and appropriate mitigation activities. An annual Enterprise Risk Management report is presented to the Audit and Ethics Committee and a presentation is made to the entire Board. In conclusion, the Board of Directors believes that the risk management processes in place for Baker Hughes are appropriate.

\section{Frontier Oil Corporation}

In 2009, Frontier Oil Corporation ranked number 383 on the Fortune 500 list, with $\$ 6.50$ billion in revenue and $\$ 80.20$ million in net income. In 2010, Frontier Oil Corporation dropped over 100 spots on the Fortune 500 list to number 488 , with $\$ 4.23$ billion in revenue and a negative $\$ 83.80$ million in net income. Frontier resides within the petroleum refining industry, although the company is substantially smaller than the competition included in this study. Frontier dedicated the first section of the 2009 Annual Report to identifying related risks. The list of potential material risk factors includes fluctuating crude oil prices, instability and volatility of the market, demand fluctuations, competition with other refining companies, terrorist attacks, and threats. The fact that Frontier has a section in the annual report dedicated specifically to risks is a promising attribute among a small scaled company; the first step to producing a well-developed Enterprise Risk Management system is to identify the company's major risk areas.

Throughout the 2009 Annual Report, the shareholders are informed of what risks are present and how these risks directly affect Frontier, although no plan is mentioned to combat these specific risks. The 2010 Proxy Statement failed to identify a Chief Executive Officer; however, the statement did contain a section detailing the responsibilities of the Board regarding risk management. The Board and committees oversee Frontier's primary risks - financial, operating, liquidity, environmental, health, and safety, as well as the strategic direction of the company. Specifically, the Audit Committee monitors the work performed by internal audits in such areas as hedging inventory positions and reviewing the risk policies followed in purchasing crude oil and other feed stocks. As such, Frontier Oil Corporation is similar in risk management organization as others included in this investigation.

\section{SUMMARY}

Table 1 summarizes company-identified and reported risks extracted from annual reports, 10-K's, 8-K's, and Proxy Statements. Additionally, related methods of mitigation and mitigation effectiveness are assigned by the reporters and, in some cases, the authors. Mitigation methods, including "Large and Diverse Portfolio" and "Financial Strength", were used repetitively by companies. All analyzed companies were financially strong, thus yielding a High rating on mitigation effectiveness. Additionally, all were large and diverse in their portfolio. When referring to "Large and Diverse Portfolio", most often, this was an indication of diversity/portfolio richness to include on-shore and off-shore, well depth, deposits of both oil and gas, quality of reserves owned, geographical location, and exploration into frontier basins and emerging energy markets. Thus, diversity also referred to drilling technology and research and development of such. All companies were strong in application of their mission. Thus, they used their money and efforts in accomplishing the mission of "Oil and Gas Exploration and Production". The term Oil and Gas Exploration and Production, in some cases, is replaced with "Energy". 
Table 1: Risk Summary Chart

\begin{tabular}{|c|c|c|}
\hline $\begin{array}{c}\text { Risks - Operating, Financial, } \\
\text { Strategic }\end{array}$ & Method of Mitigation & $\begin{array}{c}\text { Control/Mitigation } \\
\text { Effectiveness }\end{array}$ \\
\hline Start-up Timing & $\begin{array}{c}\text { Scheduling } \\
\text { Large and Diverse Portfolio } \\
\text { Financial Strength }\end{array}$ & $\begin{array}{l}\text { High } \\
\text { Moderate } \\
\text { Moderate }\end{array}$ \\
\hline Operational Outages & $\begin{array}{c}\text { Scheduling } \\
\text { Maintenance } \\
\text { Back-up systems } \\
\text { Disaster Recovery system } \\
\text { Large and Diverse Portfolio } \\
\text { Financial Strength }\end{array}$ & $\begin{array}{l}\text { High } \\
\text { High } \\
\text { High } \\
\text { High } \\
\text { High } \\
\text { High }\end{array}$ \\
\hline Reservoir Performance & $\begin{array}{c}\text { Research and Development } \\
\text { Implement new technology } \\
\text { Accuracy of Engineering Estimates } \\
\text { Large and Diverse Portfolio } \\
\text { Financial Strength }\end{array}$ & $\begin{array}{l}\text { High } \\
\text { High } \\
\text { High } \\
\text { High } \\
\text { High }\end{array}$ \\
\hline Exploration Risk & $\begin{array}{c}\text { Exploration strategy into frontier basins Diverse } \\
\text { Portfolio and Financial Strength }\end{array}$ & High \\
\hline $\begin{array}{l}\text { Volatility of Crude Oil and Natural } \\
\text { Gas Prices }\end{array}$ & $\begin{array}{c}\text { Location Diversification } \\
\text { Energy Type Diversification } \\
\text { Large and Diverse Portfolio } \\
\text { Financial Strength }\end{array}$ & $\begin{array}{l}\text { Low } \\
\text { High } \\
\text { High } \\
\text { High }\end{array}$ \\
\hline Weather Events & $\begin{array}{c}\text { Location Diversification } \\
\text { New Technology } \\
\text { Safety } \\
\text { Large and Diverse Portfolio } \\
\text { Financial Strength } \\
\end{array}$ & $\begin{array}{l}\text { Low } \\
\text { High } \\
\text { High } \\
\text { High } \\
\text { High }\end{array}$ \\
\hline Regulatory Changes & $\begin{array}{c}\text { Lobby Efforts } \\
\text { Environmental Practices } \\
\text { Ethical Practices } \\
\text { Corporate Citizenship } \\
\text { Large and Diverse Portfolio } \\
\text { Financial Strength } \\
\end{array}$ & $\begin{array}{l}\text { High } \\
\text { High } \\
\text { High } \\
\text { High } \\
\text { High } \\
\text { High }\end{array}$ \\
\hline Political Risks & $\begin{array}{c}\text { Corporate Governance } \\
\text { Large and Diverse Portfolio } \\
\text { Financial Strength } \\
\end{array}$ & $\begin{array}{l}\text { High } \\
\text { High } \\
\text { High }\end{array}$ \\
\hline Technical Risks & $\begin{array}{l}\text { Technology Advancement } \\
\text { Large and Diverse Portfolio } \\
\text { Financial Strength }\end{array}$ & $\begin{array}{l}\text { Medium } \\
\text { High } \\
\text { High }\end{array}$ \\
\hline Geo/Political Risks & $\begin{array}{c}\text { Geographical Diversification } \\
\text { Corporate Citizenship } \\
\text { World-wide Partnerships } \\
\text { Large and Diverse Portfolio } \\
\text { Financial Strength } \\
\end{array}$ & $\begin{array}{l}\text { High } \\
\text { High } \\
\text { High } \\
\text { High } \\
\text { High }\end{array}$ \\
\hline Cyber Security Risks & $\begin{array}{c}\text { Cyber Infrastructure } \\
\text { BYOD (Bring your Own Device) Management } \\
\text { Cloud Management } \\
\text { Large and Diverse Portfolio } \\
\text { Financial Strength }\end{array}$ & $\begin{array}{l}\text { High } \\
\text { High } \\
\text { High } \\
\text { High } \\
\text { High }\end{array}$ \\
\hline $\begin{array}{l}\text { Infrequent Events/Transactions } \\
\text { Risk }\end{array}$ & $\begin{array}{c}\text { Large and Diverse Portfolio } \\
\text { Financial Strength }\end{array}$ & $\begin{array}{l}\text { High } \\
\text { High }\end{array}$ \\
\hline $\begin{array}{l}\text { Changing Macroeconomic } \\
\text { Conditions Risk }\end{array}$ & $\begin{array}{l}\text { Large and Diverse Portfolio } \\
\text { Financial Strength }\end{array}$ & $\begin{array}{l}\text { Moderate } \\
\text { Moderate }\end{array}$ \\
\hline Inflation/Currency Valuation Risk & $\begin{array}{c}\text { Hedging } \\
\text { Large and Diverse Portfolio } \\
\text { Financial Strength }\end{array}$ & $\begin{array}{l}\text { Moderate } \\
\text { Moderate } \\
\text { Moderate }\end{array}$ \\
\hline
\end{tabular}


Table 2 summarizes company-reported assignment of a "Chief Risk Officer" and author assignment of "Level of Risk Appetite/Tolerance", along with "Fortune 500 Ranking". While several industries have taken steps to implement the role of Chief Risk Officer, the oil and gas companies analyzed used Management/Board/and members of the Audit committee to handle such tasks.

Industries that have taken steps to implement a Chief Risk Officer include banking, insurance, and other financial services industries, specifically financial institutions when dealing with the credit crisis that may have been caused by ineffective assessments of customer's rate of risk tolerance. Others include health care, retail, and real estate. The position of Chief Risk Officer grows more prominent in businesses as the regulations regarding risk management increase. For instance, two recent regulations include the Sarbanes Oxley Act and the Security Exchange Commissions' requirement to include an assessment of risk in the yearly proxy statement.

Table 2: Summary of Risk Appetite Rankings

\begin{tabular}{|l|c|c|c|c|c|c|}
\hline & \multicolumn{2}{|c|}{ Chief Risk Officer } & \multicolumn{2}{c|}{ Level Of Risk Appetite/Tolerance } & \multicolumn{2}{c|}{ Fortune 500 Ranking } \\
\hline & $\mathbf{2 0 0 9}$ & $\mathbf{2 0 1 0}$ & $\mathbf{2 0 0 9}$ & $\mathbf{2 0 1 0}$ & $\mathbf{2 0 0 9}$ & $\mathbf{2 0 1 0}$ \\
\hline ExxonMobil & N/A & N/A & Risk Averse & Risk Averse & 1 & 2 \\
\hline Chevron & N/A & N/A & Risk Averse & Risk Averse & 3 & 3 \\
\hline ConocoPhillips & N/A & N/A & Risk Moderate & Risk Moderate & 4 & 6 \\
\hline Valero Energy & N/A & N/A & Risk Moderate & Risk Moderate & 10 & 26 \\
\hline Baker Hughes & N/A & N/A & Risk Moderate & Risk Moderate & 227 & 243 \\
\hline Frontier Oil Corporation & N/A & N/A & Risk Moderate & Risk Moderate & 383 & 488 \\
\hline
\end{tabular}

\section{CONCLUSION}

At the end of 2009, the U.S. Securities and Exchange Commission began requiring all "U.S. publiclytraded companies to include in their annual proxy statements information about the Board's involvement in risk oversight." Ideally, the SEC's reporting requirement will require the oil and gas industry to further develop its' Enterprise Risk Management systems. In conclusion, companies ranking higher on the Fortune 500 list appeared to have more mature and developed approaches to implementing Enterprise Risk Management systems.

In addition, several industries have taken steps to implement the role of Chief Risk Officer. A few examples include banking, insurance, and other financial services industries. Oil and gas companies place such responsibilities squarely on the Audit committee and its infrastructure. Some industries have adopted the position of Chief Risk Officer, including health care, retail, and real estate. The position of Chief Risk Officer grows more prominent in businesses as the regulations regarding risk management increase.

In conclusion, all six corporations followed the Securities and Exchange Commission reporting requirements which were implemented at the close of 2009. Furthermore, each company's 2010 Proxy Statement included a section detailing information about the Board's involvement in the risk oversight process. Moreover, many of the 2010 Proxy Statements broke down the Board's risk oversight responsibility among the committees and explained the process of identifying, assessing, mitigating, and reporting on the corporation's risks.

\section{AUTHOR INFORMATION}

Violet C. Rogers is a Professor of Accountancy at Stephen F. Austin State University. Her teaching interests include Auditing, Regulation, and Oil and Gas Accounting. Her research interests include teaching areas and Environmental Accounting, Ethics and Risk. She has previous experience in public accounting and 25 years of educational experience. Her $\mathrm{PhD}$ is from the University of North Texas. E-mail: vrogers@sfasu.edu (Corresponding author)

Jack R. Ethridge is a Professor of Accountancy at Stephen F. Austin State University. His teaching interests include Auditing, Advanced Accounting, and Theory. His research interests include teaching areas and risk analysis and accounting reporting. He has over 30 years of educational experience. His $\mathrm{PhD}$ is from University of Arkansas. E-mail: jethridge@sfasu.edu 


\section{REFERENCES}

1. Allen, S. (2005, May 12). The rise of the chief risk officer.

2. Baker Hughes INC.2009. Form 10-k (Annual Report).

3. Baker Hughes INC.2010. 2010 Proxy Statement.

4. Baker Hughes INC.2010. Form 10-k (Annual Report).

5. Beasley, Mark, Bruce Branson and Bonnie Hancock. 2010. "Report on the Current State of Enterprise Risk Oversight: $2^{\text {nd }}$ Edition.” American Institute of Certified Public Accountants (AICPA) Business, Industry \& Government Team and the ERM Initiative at North Carolina State University.

6. Chevron. 2009. 2009 Annual Report.

7. Chevron. 2010. 2010 Proxy Statement.

8. ConocoPhillips. 2010. 2010 Proxy Statement.

9. ConocoPhillips. 2009. Building on Strengths; 2009 Summary Annual Report.

10. ExxonMobil. 2009. 2009 Annual Report.

11. ExxonMobil 2011 Corporate Citizenship Report. And 2009, 2007.

12. ExxonMobil. 2010. 2010 Proxy Statement.

13. ExxonMobil The Lamp. 2012. Produced by the Public \& Government Affairs Department.

14. Frontier Oil Corporation. 2009. 2009 Annual Report.

15. Frontier Oil Corporation. 2010. 2010 Proxy Statement.

16. Lee, C. R. \& Shimpi, P. The Chief Risk Officer: What does it look like and how do you get there?. Risk Management Magazine.

17. Valero Energy Corporation. 2009. 2009 Summary Annual Report.

18. Valero Energy Corporation. 2010. 2010 Proxy Statement. 